\title{
Sacral Cutaneous Clues to Underlying Spinal Abnormalities
}

\author{
Mee Hong, M.D., Yeon Kyung Lee, M.D., Sun Young Ko, M.D., Son Moon Shin, M.D., Byoung Hee Han,M.D.,* \\ and Kyung A Kim, M.D. ${ }^{\dagger}$ \\ Departments of Pediatrics, Diagnostic Radiology*, Cheil General Hospital \& Women's Health Care Center Kwandong University \\ College of Medicine, Seoul, Korea \\ Department of Pediatrics ${ }^{\dagger}$, National Police Hospital, Seoul, Korea
}

\section{ABSTRACT}

Purpose: Sacral cutaneous lesions in newborns are associated with numerous spinal abnormalities. Early detection is important, because spinal abnormalities may cause neurological symptoms. Radiologic screening tests have been performed on newborns with sacral cutaneous lesions. This study aimed to substantiate the associations between sacral cutaneous lesions and spinal abnormalities.

Methods: From January 2007 until November 2013, we retrospectively reviewed the charts of 743 newborns with sacral cutaneous lesions that included sacral dimples, which were deeper than $5 \mathrm{~mm}$ and situated further than $2.5 \mathrm{~cm}$ from the anus, deviated gluteal furrow, hairy patch, hemangioma, dyspigmentaion, and the presence of mass, and skin tag.

Results: 743 newborns with sacral cutaneous lesions were examined, including 24 newborns with abnormal ultrasonographic images. Tethered cord which affected 18 (2.4\%) of the newborns, was the most commonly found spinal abnormaility. Of these 9 newborns had other spinal abnormalities in addition to tethered cord including lipoma, cyst, spina bifida occulta, lipomyelomeningocele, and dermal sinus tract, and 9 newborns had isolated tethered cord only. Other spinal abnormalities found included isolated lipoma ( 3 newborns, $0.4 \%$ ), and subarachnoid cyst (2 newborns, $0.3 \%$ ), and of the 2 newborns ( $0.3 \%)$ who had dermal sinus tract, 1 also had a lipoma and the other also had a tethered cord. Normal variants included coccygeal pit (43 newborns, 5.8\%), and ventriculus terminalis (10 newborns, 1.4\%). Of the 646 newborns with isolated sacral cutaneous lesion, 11 (1.7\%) had abnormal ultrasonographic images, and of the 97 newborns with combined sacral cutaneous lesions, 13 (13.4\%) had abnormal ultrasonograpic images.

Conclusion: Sacral cutaneous lesions in newborns can be associated with spinal abnormalities, and the strongest marker of spinal abnormality is a combined lesion. Therefore, ultrasonography should be performed on newborns who present with sacral cutaneous lesions to detect and investigate any underlying spinal abnormalities.

Key Words: Cutaneous lesion, Spinal abnormality, Ultrasonography
Received: 31 December 2013

Revised: 10 February 2014

Accepted: 14 February 2014

Correspondence to:

Yeon Kyung Lee, M.D.

Department of Pediatrics, Cheil

General Hospital, Kwandong

University College of Medicine, 1-19 Mukjeong-dong, Jung-gu, Seoul 100-380, Korea

Tel: +82-2-2000-7771

Fax: +82-2-2000-7778

E-mail: ykleeped@hanmail.net

Copyright(c)

By Korean Society of Neonatology.

All right reserved.

This is an Open-Access article distributed under the terms of the Creative Commons Attribution Non-Commercial License (http://creativecommons.org/licenses/ by-nc/3.0), which permits unrestricted non-commercial use, distribution, and reproduction in any medium, provided the original work is properly cited. 
서론

피부와 신경조직은 외배엽에서 발생하기 때문에 동시에 이상 이 나타날 수 있으며 다양한 천골부 피부병변은 척추병변과 연관 이 있어 피부병변이 있는 경우 선별검사를 하는 기준이 되어왔다 ${ }^{1,2)}$. 신생아에서 나타날 수 있는 천골부 피부병변으로는 피부함몰, 비대칭 둔열(deviated gluteal furrow), 종괴(mass), 털, 혈관종, 색소침착이상(dyspigmentation), 선천성 피부결손(aplasia cutis congenita) 등이 있으며, 속박척수(tethered cord)를 비롯하여, 피 부동관(dermal sinus tract), 지방종, 숨은척추갈림증(spina bifida occulta) 등의 척추병변과 연관이 있을 수 있다 ${ }^{1,2)}$. 척추병변이 동 반되는 경우에 신경학적 증상이 명확하지 않아서 걷기 전까지 증 상이 나타나지 않는 경우가 많으멱), 1 세 이후에 요로 감염, 하지 변형, 하지 위약감, 하지 경직, 방광 기능이상 등의 증상이 발현할 수 있으므로 조기 발견하여 치료하는 것이 중요하다 ${ }^{4}$. 국외에서 는 척추병변에 대한 천골의 피부병변의 연관성에 관한 연구가 있 었으나 국내에서는 이에 대한 보고가 없다. 따라서 본 연구는 신 생아에서 발견될 수 있는 천골부 피부병변과 잠재된 척추병변과 의 연관성에 대해서 알아보고자 하였다.

\section{대상 및 방법}

2007년 1월부터 2013년 11월까지 제일병원에서 태어난 49,344 명의 신생아 중 천골부 피부병변을 보여 초음파 검사를 시 행한 743 명의 산전 초음파 결과, 남녀 성비, 동반 기형 등의 출생 력, 초음파 검사를 시행한 연령 및 적응증, 검사 결과를 후향적으 로 의무기록을 조사하여 분석하였다. 항문 상방 $2.5 \mathrm{~cm}$ 이상, 깊 이 $5 \mathrm{~mm}$ 이상인 천골부 피부함몰과 비대칭 둔열, 주변 부위의 털보다 길고 두꺼운 털이 있는 경우, 과다색소침착 및 저색소침 착을 포함한 색소침착이상, 낭종 및 주변 부위 조직에 비해 융기 된 종괴, 피부연성섬유종, 혈관종 등의 피부병변에서 초음파 검 사를 시행하였으며, 단일병변과 복합병변의 초음파 결과를 비교
하였다. 초음파 기기는 LOGIQ 9 Scanner (GE medical System, Milwaukee, WI, U.S.A) 12 MHZ linear transducer를 사용하였으 며, 척수원추의 위치, 종말끈의 두께 및 음영, 요천추부위의 종괴 여부를 소아영상의학 전문의가 분석하였다.

통계는 SPSS for window 18.0 (SPSS Inc., Chicago, IL, USA)로 분석하였으며, Chi-square test를 이용하였고 $P$ 값이 0.05 미만인 경우에 통계적 유의성이 있는 것으로 판단하였다.

\section{결과}

2007년 1월부터 2013년 11월까지 출생한 신생아 49,344명 중 천골부 피부병변으로 초음파 검사를 시행한 경우는 총 743 명 (1.5\%)이었다. 이들 중 미숙아가 74명으로 재태주수 27주에서 29 주6일까지가 4명, 30주에서 36주6일까지가 70명이었고, 만삭아 가 669 명이었다. 미숙아의 출생 체중은 $450 \mathrm{~g}$ 에서 $1,000 \mathrm{~g}$ 미만이 3 명, $1,000 \mathrm{~g}$ 이상 $1,500 \mathrm{~g}$ 미만이 12 명, $1,500 \mathrm{~g}$ 이상 $2,500 \mathrm{~g}$ 미만 이 35 명, $2,500 \mathrm{~g}$ 이상이 24 명으로 퇴원 전 체중이 $2 \mathrm{~kg}$ 이상 되었 을 때 초음파 검사를 시행하였다. 남아가 378 명, 여아가 365 명으 로 남아가 약간 더 많았으며, 초음파를 시행한 시기는 생후 일주 일 이내가 536명으로 가장 많았고, 1 주일에서 1 개월 사이가 116 명, 1 개월에서 6개월 사이가 91 명이었다.

피부병변 중 단일병변으로는 피부함몰이 557명(75\%)으로 가 장 많았고, 그 외 털, 피부연성섬유종, 색소침착이상 순이었으며 (Figure 1), 복합병변 중에서는 천골부 피부함몰과 털이 함께 있는 경우가 72 명 $(9.7 \%)$ 으로 가장 많았다. 단일병변의 경우, 646 명 중 초음파검사에서 비정상 소견을 보인 신생아는 11 명으로 $1.7 \%$ 의 발생률을 보였다. 이 중 천골부 피부함몰을 보인 신생아 557명 중 7명에서 비정상 소견이 발견되었으며, 피부연성섬유종의 경우 28 명 중 2 명, 색소침착이상은 11 명 중 1 명, 종괴의 경우 9명 중 1 명 에서 비정상 소견을 보였고, 털만 있는 경우에서는 비정상 소견이 발견되지 않았다. 복합병변의 경우, 97 명 중 비정상 소견은 13 명 으로 13.4\%의 높은 발생률을 보였으며(OR 8.934; 95\% CI 3.878-

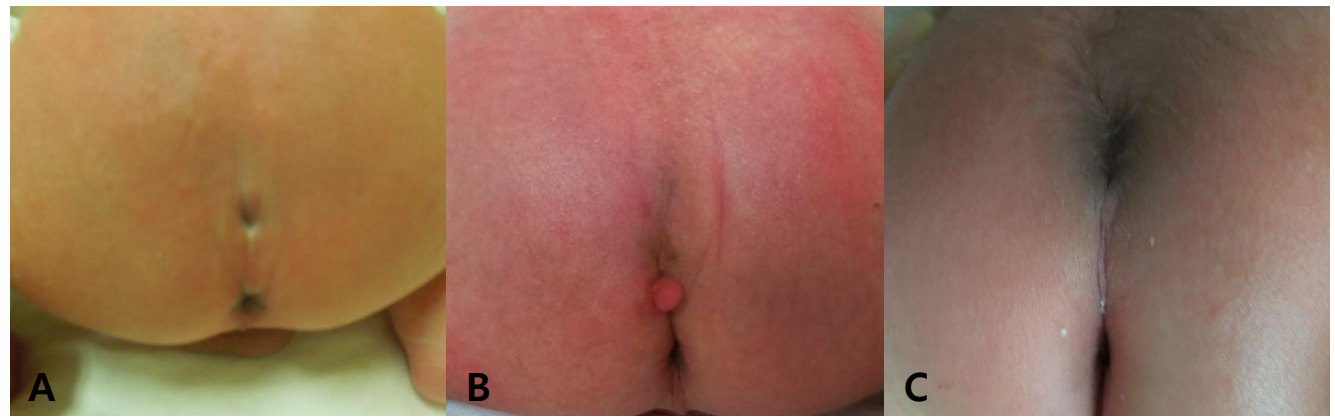

Figure 1. Clinical features of lumbosacral cutaneous lesions. (A) Dimple; (B) Skin tag; (C) Hairy patch. 
$20.582 P<0.01)$ 특히 세가지 병변이 복합되었던 5 명은 모두 비 정상 소견을 보였다. 두가지 병변이 복합된 신생아는 92 명으로 피 부함몰과 털이 동반된 72 명 중 비정상 소견은 1 명이었으며, 피부 함몰과 피부연성섬유종이 동반된 경우는 12 명으로 비정상 소견 은 3 명이었다. 그 외 피부함몰이 2 개 이상인 경우 4 명 중 2 명에서 비정상 소견을 보였고, 피부함몰과 혈관종이 동반된 신생아는 2 명 모두 비정상 소견을 보였으며, 피부연성섬유종과 색소침착이 상을 동반한 2명은 모두 정상이었다. 세가지 병변이 복합된 신생 아는 5명으로 피부함몰과 털, 종괴를 동반한 경우가 3명, 피부함 몰 및 색소침착이상, 종괴가 동반된 경우가 1 명, 피부함몰과 함 께 피부연성섬유종 및 종괴가 동반된 경우가 1명으로 모두 비정 상 소견을 보였다. 잠재된 척추병변은 속박척수(tethered cord) 가 18 명 (2.4\%)으로 가장 많았으며 그 중 9명은 지방종, 낭종, 피부 동관(dermal sinus tract), 숨은척추갈림증(spina bifida occulta), 지방척수수막류(lipomyelomeningocele) 등의 다른 병변을 동 반하였다. 그 외 단순 지방종 3 명, 지주막 낭종 2 명이 있었고 피 부동관은 2 명으로 1 명은 지방종, 1 명은 속박척수를 동반하였다. 정상 변형은 53명으로 미부 함몰(coccygeal pit) 43명, 종말뇌실 (ventriculus terminalis) 10명이었다(Table 1).

이들 중 산전 초음파 검사에서 척추 이상이 있었던 신생아는 1 명으로 천골 부정 배열(Abnormal alignment)을 보였으며 출생 후
신체검진에서 항문 위 약 $3 \mathrm{~cm}$, 깊이 $5 \mathrm{~mm}$ 이상의 피부 함몰과 함께 $3 \mathrm{~cm}$ 크기의 종괴와, 저색소침착을 보여 시행한 초음파 검사 에서 지방종을 동반한 속박척수로 진단되었다(Figure 2).

다른 기형을 동반한 환아는 2 명으로 모두 천골부 피부함몰을 보여 시행한 초음파 검사에서 속박척수 소견을 확인하였으며 흉 추 반척추뼈와 오른손 다지증을 동반한 환아가 1 명, 오른손 다지 증과 구개열 및 안검하수가 동반된 환아가 1 명 있었다.

\section{고찰}

신생아에서 천골부 피부병변의 정확한 발생 빈도는 알려져 있 지 않으며 여러 연구에서 $2.9 \%$ 에서 $7.1 \%$ 로 다양하게 보고하고 있 다 ${ }^{5-7)}$. 본 연구에서는 $1.5 \%$ 로 낮은 발생률을 나타내었는데 이는 항문 상방 $2.5 \mathrm{~cm}$ 이하, 깊이 $5 \mathrm{~mm}$ 이하의 단순 천골부 피부함몰 은 포함시키지 않았기 때문으로 생각된다. Liat Ben-Sira 등 ${ }^{11)}$ 은 단일병변 중에서 가장 흔한 병변으로는 천골부 피부함몰, 복합병 변으로는 천골부 피부함몰과 털이 혼합된 것으로 보고하였으며 본 연구에서도 같은 결과를 나타내었다.

천골부에서 나타날 수 있는 피부병변으로는 피부함몰, 비대칭 둔열, 종괴, 털, 혈관종, 피부연성섬유종, 색소침착이상, 선천성 피

Table 1. Ultrasound Examinations due to Cutaneous Markers

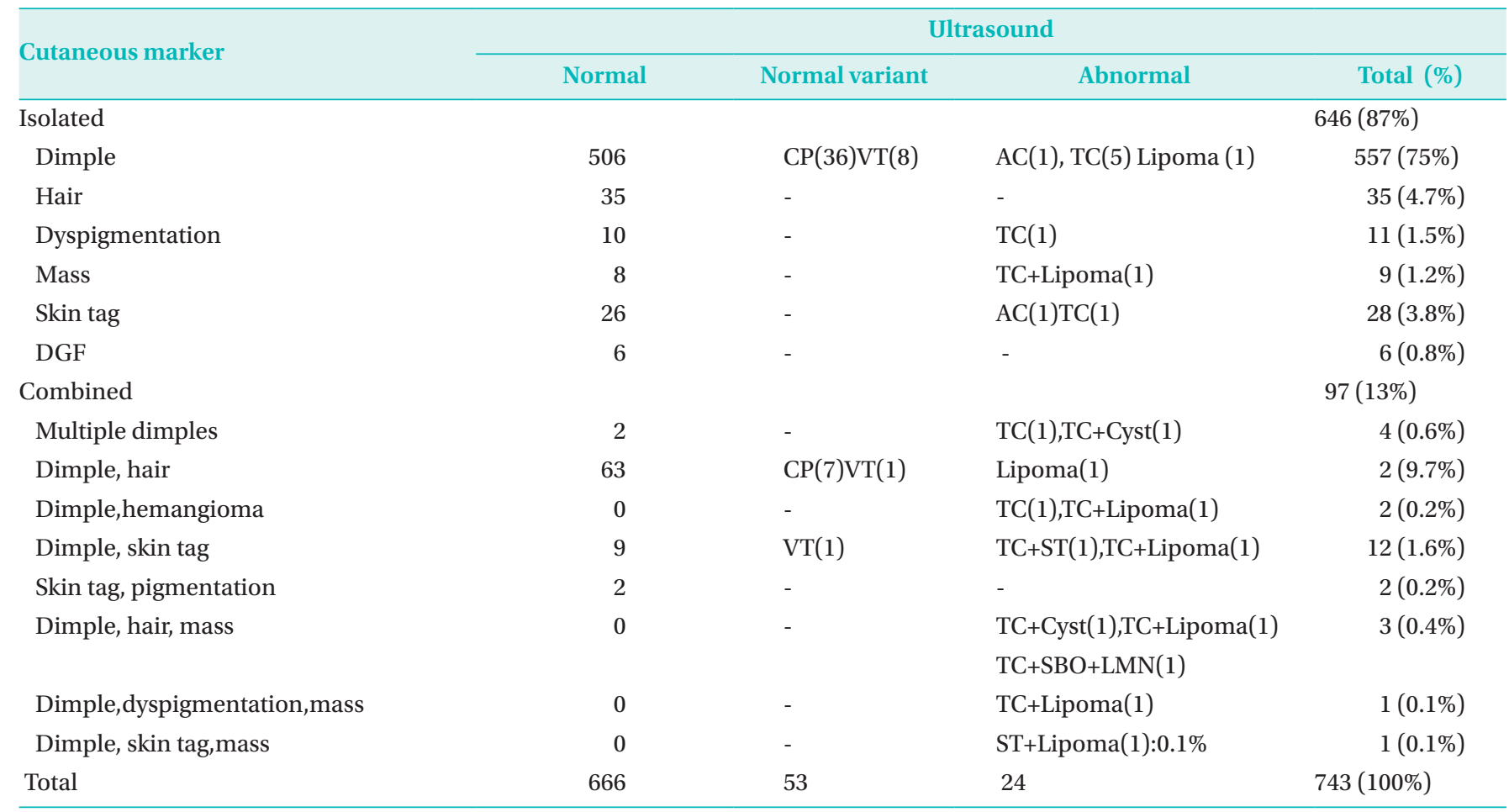

Abbreviations: CP, coccygeal pit; VT, ventriculus terminalis; TC, tethered cord; AC, arachnoid cyst; ST, sinus tract; SBO, spina bifida occulta; LMN, lipomyelomeningocele; DGF, deviated gluteal furrow. 


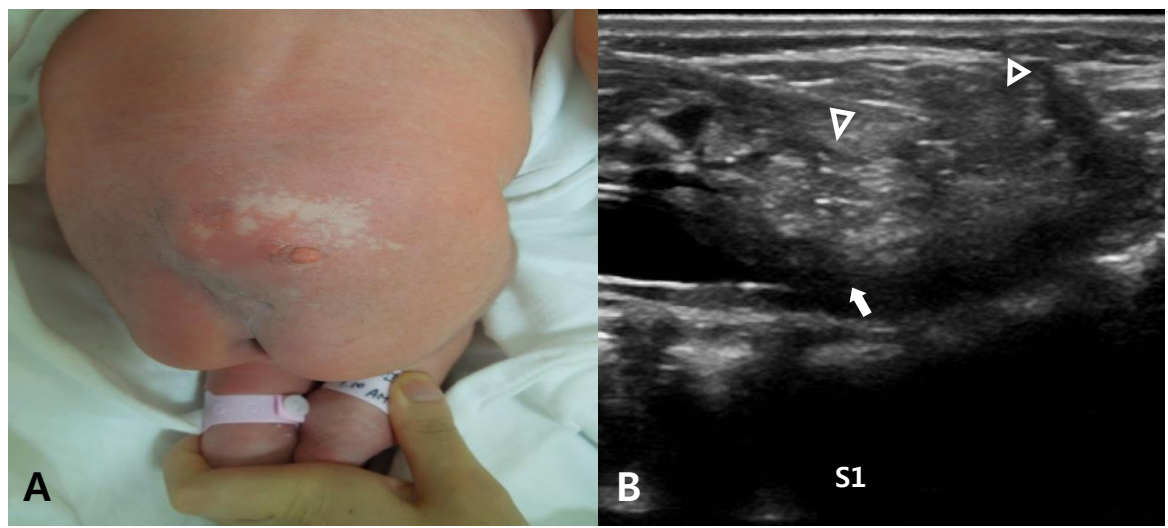

Figure 2. Newborns with combined sacral cutaneous lesions. (A) Clinical characteristics of a sacral dimple with hypopigmentation and a mass. (B) A sonogram showing a longitudinal view of a tethered cord (arrow) with a lipoma (arrow heads).

부결손 등이 있다 ${ }^{1,2)}$. 천골부 피부함몰은 신생아의 척추 검진에서 가장 흔하게 발견되는 피부병변으로 천미골부에서 발견되는 피 부함몰을 총칭하며 다른 피부병변이 동반되지 않은 낮은 위치의 단순 천골부 피부함몰의 경우 척추병변과 연관이 없는 것으로 알 려져 있다 ${ }^{4)}$ Kriss와 Desai' ${ }^{5}$ 의 연구에서 항문 상방 $2.5 \mathrm{~cm}$ 이하 깊 이 $5 \mathrm{~mm}$ 이하의 천골부 피부함몰을 보인 160명에 대해 초음파 검사를 시행한 결과 모두 정상 소견을 보였으며, Robinson 등릐 의 연구에서도 86 명 모두 정상 소견을 보였다. 이를 근거로 본원에서 도 항문 상방 $2.5 \mathrm{~cm}$ 이상, 깊이 $5 \mathrm{~mm}$ 이상의 피부함몰에 대해서 초음파를 시행하고 있으며, 다른 병변을 동반하지 않은 피부함몰 은 557명으로 이 중 7명의 신생아에서 지주막 낭종, 속박척수, 지 방종 등의 소견을 보였고 다른 병변을 동반한 피부함몰은 95 명으 로 이 중 13 명에서 속박척수, 지방종, 피부동관 등의 소견이 관찰 되었다. 두껍고 구불구불하며 긴 털이 삼각형 또는 마름모 형태로 밀집해 있는 경우 faun tail이라 하며 이는 척추병변과 연관이 있으 나 다른 병변을 동반하지 않은 단순 털병변은 척추병변과는 연관 성이 없는 것으로 알려져 있다 ${ }^{1,8)}$. 본 연구에서는 faun tail을 보인 신생아는 없었고 단순 털병변만 있는 35명 모두 정상이였으며, 다 른 병변을 동반한 털병변의 66명 신생아 중 4명에서 속박척수, 지 방종 등의 소견을 보였다. 피부연성섬유종은 지방척수수막류와 같은 척추병변과 연관이 있는 것으로 알려져 있으며, 본 연구에서 피부연성섬유종만 있었던 28명 중 1명은 지주막 낭종, 1 명은 속박 척수 소견을 보였으며, 다른 병변을 동반한 15 명 중 4 명에서 속박 척수, 지방종, 피부동관 등의 소견이 보였다. 색소침착이상은 신 경섬유종(neurofibroma), 지방척수수막류와 같은 척추병변을 동 반할 수 있는 것으로 알려져 있으며"), 본 연구에서 다른 병변을 동 반하지 않은 색소침착이상은 10 명으로 그 중 1 명은 속박척수소견 을 보였으며 다른 병변을 동반한 3 명 중 1명은 속박척수와 지방종 이 동반되었다. 혈관종은 속박척수와 같은 척추병변과 관련이 있
으며 Albright 등 ${ }^{10)}$ 은 7명의 혈관종 환아에서 속박척수가 동반된 사례를 보고하였고, 본 연구에서도 피부함몰과 함께 혈관종을 동 반한 2명 모두 속박척수 소견을 보였다. 선천성 피부결손은 척수 수막류(myelomeningocele)와 같은 척추병변을 동반할 수 있는 것으로 알려져 있으남본연 연구에서 천골부에 선천성 피부결손을 보인 사례는 없었다. 비대칭 둔열은 다른 병변을 동반 하지 않을 때 척추병변과 연관이 없는 것으로 알려져 있으며 ${ }^{1,11}$, 본 연구에 서도 다른 병변을 동반하지 않은 비대칭 둔열을 보인 신생아 6명 모두 정상이었다.

천골부 피부병변은 척추병변을 예측하는 중요한 지표로서 선 별검사 방법으로 초음파 검사가 비침습적이며 비용 대비 효율적 이기 때문에 사용되고 있다. 5-6개월 후에는 척추 후궁의 골화가 일어나기때문에 6 개월 이내에 시행해야 하며 ${ }^{1,5,11}$, 본 연구에서도 모두 6개월 이내에 초음파 검사를 시행하였다.

속박척수 증후군은 척수에 과도한 장력이 가해짐으로 나타나 는 증상과 징후들을 말하며 주로 척추갈림증과 연관되어 있으며 낮은 척수 위치(제 2번-제 3번 허리뼈 이하)가 특징이다. 요실금, 척추 측만증이 나타날 수 있고 항문과 직장의 기형이 있을 수 있 으며, 신체검사상 피부병변 외 양쪽 다리 길이의 차이, 근 비대칭 이 있을 수 있다. 보존적 치료는 증상의 완화에만 국한되기에 수 술적 치료로 장력을 제거해야 하고 3 세 이전에 수술을 하는 것이 예후 향상에 도움이 된다 ${ }^{12)}$. 본 연구에서는 동반병변 없이 속박척 수만 보인 경우가 9명, 다른 이상을 동반한 경우가 9명으로 지방 종, 낭종, 피부동관, 숨은척추갈림증, 지방척수수막류, 종말뇌실 등을 동반하였으며 지방종을 동반한 경우가 5명으로 가장 많았 다. 척수 지방종은 척수강내 지방과 섬유조직의 덩어리로 지방척 수수막류, 종말끈(filum terminale)의 섬유지방종, 경막내 지방종 으로 분류되며, 감각이상, 마비, 신경성 방광과 같은 신경학적 증 상을 일으킬 수 있다. 본 연구에서는 다른 병변을 동반하지 않은 
단순 지방종은 3 명으로 모두 종말끈 내에 위치하였다. 지방척수 수막류는 속박척수를 동반할 수 있고 척추갈림증과 연관되어 있 으며 본 연구에서도 지방척수수막류와 속박척수, 척추갈림증이 동반된 사례가 1 례 있었다. 거미막 낭종은 거미막(arachnoid)이 나 경막(duramater)을 형성하는 과정에서 발달 이상으로 생기며 큰 낭종이 척수를 누르거나 척수 변위를 일으킨다. 동반 기형으로 뇌수종, 뇌량(corpus callosum)의 무형성 또는 저형성이 있을 수 있다. 본 연구에서 거미막 낭종은 2 명으로 1 명은 뇌초음파 검사에 서 정상소견을 확인하였고, 1 명은 추가적인 검사를 시행하지 않 았다. 피부동관은 피부에서 척수, 마미신경총(cauda equina) 또는 거미막과 연결되는 상피세포로 둘러싸인 관으로 작은 피부함몰 이나 구멍으로 발현한다. 반복적인 뇌수막염, 경막외 또는 경막하 농양, 골수강내 척수 농양을 일으킬 수 있으며 피부동관의 위치가 중앙선을 벗어날 경우 척수 내 유피 낭종(dermoid cyst) 또는 표 피 낭종(epidermoid cyst)이 동반되어 신경을 압박하여 신경학적 증상을 일으키기도 한다 ${ }^{13)}$. 본 연구에서 피부동관만 단독으로 보 인 경우는 없었고 지방종이 동반된 경우가 1명, 속박척수가 동반 된 경우가 1 명 있었다. 피부동관과 감별해야 할 소견으로 미부 함 몰(coccygeal pit)이 있다. 피부동관은 주로 둔열(gluteal cleft)상 부에 위치하며 관(tract)의 방향이 두위 쪽을 향하나 미부 함몰은 둔열 내에 위치하며 관의 방향이 아래쪽을 향한다 ${ }^{14)}$. 본 연구에서 도 피부동관을 보인 2명은 피부함몰이 둔열 상방에 위치하고 초 음파 검사상 관(tract)의 방향이 두위쪽을 향하는 것을 확인하였 으며, 미부 피부함몰의 경우 43 명 모두 피부함몰이 둔열 내에 위 치하며 초음파 검사에서 관의 위치가 아래쪽을 향하는 것을 확인 하였다. 미부 피부함몰은 경막내 병변과는 연관되지 않으면) 추 가적인 검사나 치료가 필요하지 않는 것으로 알려져 있다 ${ }^{15}$. 종말 뇌실은 정상 변형의 하나로 척수 종말끈에서 기인하는 뇌실막 세 포(ependymal cell)로 이루어진 타원형, 낭성 구조물로 척수원추 의 끝부분에 위치하며 두께 2-4 mm, 길이 8-10 mm로 임상적인 증상이 없어 정상 변형으로 본다 ${ }^{13)}$.

신생아의 척추병변은 어느 정도 병이 진행되어 하지 위약감, 하 지 경직, 하지 변형, 감각 이상, 마비, 방광기능 이상 등의 신경학 적 증상이 나타나기 전까지는 진단이 늦어지는 경우가 많아 조기 발견 및 치료에 어려움이 많다. 따라서 천골부 피부병변이 있는 경우 신경학적 증상을 일으킬 수 있는 척추병변이 동반될 수 있으 므로 초음파 검사가 필요하며, 특히 2가지 이상의 병변이 혼합된 경우는 척추병변을 강하게 시사하는 소견이므로 반드시 초음파 검사가 시행되어야 한다.

\section{REFERENCES}

1) Guggisberg D, Hadj-Rabia S, Viney C, Bodemer C, Brunelle F, Zerah M, et al. Skin markers of occult spinal dysraphism in children: a review of 54 cases. Arch Dermatol 2004;140:110915.

2) Robinson AJ, Russell S, Rimmer S. The value of ultrasonic examination of the lumbar spine in infants with specific reference to cutaneous markers of occult spinal dysraphism. Clin Radiol 2005;60:72-7.

3) Sasani M, Asghari B, Asghari Y, Afsharian R, Ozer AF. Correlation of cutaneous lesions with clinical radiological and urodynamic findings in the prognosis of underlying spinal dysraphism disorders. Pediatr Neurosurg 2008;44:360-70.

4) Lee ACW, Kwong NS, Wong YC. Management of sacral dimples on routine newborn examination : a case series and review. HKJ Paediatr 2007;12:93-5.

5) Kriss VM, Desai NS. Occult spinal dysraphism in neonates: assessment of high risk cutaneous stigmata on sonograohy. AJR Am J Roentgenol 1998;171:1687-92.

6) Powell KR, Cherry JD, Hougen TJ, Blinderman EE, Dunn MC. A prospective search for congenital dermal abnormalities of the craniospinal axis. J Pediatr 1975;87:744-50.

7) Henriques JG, Pianetti G, Henriques KS, Costa P, Gusmao S. Minor skin lesions as markers of occult spinal dysrapphismprospective study. Surg Neurol 2005;63 Suppl 1:S8-12.

8) Bak H, Kim JY, Chung YL, Kim SC. A case of faun tail associated with tethered cord syndrome. Korean J Dermatol 2004; 42:781-3.

9) Davis DA, Cohen PR, George RE. Cutaneous stigmata of occult spinal dysraphism. J Am Acad Dermatol 1994;31:892-6.

10) Albright AL, Gartner JC, Wiener ES. Lumbar cutaneous hemangiomas as indicators of tethered spinal cords. Pediatrics 1989;83:977-80.

11) Ben-Sira L, Ponger P, Miller E, Beni-Adani L, Constantini S. Low-risk lumbar skin stigmata in infants: the role of ultrasound screening. J Pediatr 2009;155:864-9.

12) Lew SM, Kothbauer KF. Tethered cord syndrome: an updated review. Pediatr Neurosurg 2007;43:236-48.

13) Unsinn KM, Geley T, Freund MC, Gassner I. US of the spinal cord in newborns: spectrum of normal findings, variants, congenital anomalies, and acquired diseases. Radiographics 2000;20:923-38.

14) Ha DW, Yoon SH, Kim SH, Shin YS, Ahn YH, Cho KH, et al. Clinical comparison of congenital dermal sinus tract and coccygeal pit. Korean J Pediatr Neurosurg 2006;3:81-5. 


\section{신생아의 천골부 피부병변과 잠재된 척추병변과의 연관성}

\section{관동대학교 의과대학 제일병원 소아청소년과, 진단방사선과*, 경찰병원 소아청소년과 ${ }^{\dagger}$}

홍미 · 이연경 · 고선영 · 신손문 · 한병희* 김경아

목적: 신생아의 천골부 피부병변은 다양한 척추병변과 관련되어 있다. 척추병변이 있을 경우 신경학적 증상들이 나타 날 수 있으므로 조기에 발견하는 것이 중요하기 때문에 피부병변을 가진 신생아에 대하여 선별검사를 시행해 왔 다. 본 연구는 천골부 피부병변과 척추병변과의 연관성에 대해 알아보고자 하였다.

방법: 2007년 1월부터 2013년 11월까지 제일병원에서 태어난 신생아 중 천골부에 항문 상방 $2.5 \mathrm{~cm}$ 이상, 깊이 $5 \mathrm{~mm}$ 이 상의 피부함몰 및 비대칭 둔열, 털, 혈관종, 색소침착, 종괴 등의 피부병변으로 초음파 검사를 시행한 743 명의 의 무기록을 후향적으로 분석하였다.

결과: 천골부 피부병변으로 초음파 검사를 시행한 743 명중 이상 소견을 보인 경우는 24 명 $(3.2 \%)$ 이며 속박 척수 (tethered cord)가 18명(2.3\%)으로 가장 많았고 그 중 9명은 지방종, 숨은척추갈림증(spina bifida occulta), 지방척 수수막류(lipomyelomeningocele), 낭종, 피부동관(dermal sinus tract)의 다른 병변을 동반하였다. 그 외 단순 지 방종 3 명 $(0.4 \%)$, 지주막 낭종 2 명(0.3\%) 그리고 피부동관은 2 명(0.3\%)으로 1명은 지방 종, 1 명은 속박척수를 동반 하였다. 정상변형을 보인 경우는 53 명으로 미부 함몰(coccygeal pit)이 43명, 종말 뇌실(ventriculus terminalis)이 10 명 이었다. 한가지 피부병변이 있는 646 명중 이상 소견을 보인 환아는 11 명으로 $1.7 \%, 2$ 가지 이상 복합 피부병 변이 있는 97 명중 이상 소견은 13 명으로 $13.4 \%$ 였다.

결론: 천골부 피부병변이 있는 경우 신경학적 증상을 일으킬 수 있는 척추병변이 동반될 수 있으므로 초음파 검사가 필 요하며, 특히 2가지 이상의 병변이 혼합된 경우 척추병변을 강하게 시사하는 소견이므로 반드시 초음파 검사가 시행되어야 한다. 